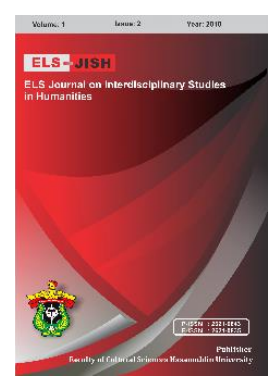

ELS-JISH

ELS Journal on Interdisciplinary Studies on Humanities

Volume 1 Issue 2, 2018

ISSN (print) : 2621-0843

ISSN (online) : 2621-0835

Homepage : http://journal.unhas.ac.id/index.php/jish

\title{
Forms and Meanings of Stative Verbs in Progressive Tense: a Corpus Linguistics Research
}

\author{
Upi Laila Hanum ${ }^{1}$
}

e-mail:phi.lailahanum@yahoo.com

\begin{abstract}
Semantics is the field of linguistic concerned with the study of meaning in language. The aims of the research are to analyze the forms and meanings of the stative verbs in progressive tense in corpora. The data of this research were obtained from Corpus of Contemporary American English (COCA) and British National Corpus (BNC). The data of the corpora used descriptive qualitative. The result of the research shows that the stative verbs are found and used in progressive tense. The stative verbs appeared in all types of progressive tense except future perfect progressive. The use of the stative verbs in progressive tense took place due to overgeneralization in the use of the native speakers' form of American and British English. The stative verbs in progressive tense used to express temporariness, emotiveness, comprehension and mixed categories of meaning; temporariness and emotiveness, temporariness and tentativeness. Temporariness meaning almost appeared in all types of progressive. Stative verbs in progressive tense indirectly stated temporariness in stative sense of meaning, is contrary to the rules of English grammar.
\end{abstract}

Keywords: : Stative Verbs, Progressive Tense, Corpus

How to cite: Hanum, U, L. (2018). Forms and Meanings of Stative Verbs in Progressive Tense: a Corpus Linguistics Research. ELS Journal on Interdisciplinary Studies in Humanities, 1 (2), 184-190.

\section{Introduction}

Language is the basic capacity that distinguishes humans from all other living beings. According to Fromkin \& Rodman (1974), the possession of language, more than any other attribute, distinguishes man from other animals. To understand man's humanity one must understand the language that makes him human. Language, therefore, remains potentially as a communicative medium capable of expressing ideas and concepts as well as moods, feelings and attitudes.

As one of the most used languages in the world, English connects people from different countries with different languages. English is the single most important language in the world, being the official or de facto language of the United Kingdom, the United States of America, Canada, Australia, New Zealand, South Africa, and dozens of others (Huddleston et al., 2002). Besides, it also becomes lingua franca of internet, as well as in the science and scholarship (Quirk et al., 1992).

English as the international language has its own system and grammatical structure and like all languages, it changes over time from one generation to another. One of the changes in grammatical area of English is about aspect, especially in progressive aspect. According to

\footnotetext{
${ }^{1}$ University of Science and Technology Jayapura 
Griffiths (2006), aspect is a grammatical category that reflects the way in which the action of verb is viewed with respect to time. The change of aspect can be seen from the use of verbs which are not compatible with the progressive. Leech (2004), states that:

"The most difficult over the use of the progressive aspect arises with classes of the verbs which are normally incompatible with the progressive: these can be called anti-progressive verbs, because of their 'unfriendliness' to the progressive".

Swan (2009), also quotes that some verbs are never or hardly ever used in progressive forms when they have certain meanings. These verbs are called by Swan (2009), as nonprogressive verbs. Besides, according to Graver (2001), the progressive indicates temporal time or temporariness while stative verbs imply permanence. These kinds of verbs are not normally used in progressive because they describe a state rather than an action. Some verbs refer to mental states (e.g. know, think, believe and etc.) and some others refer to the use of the senses (e.g. smell, taste, and etc). However, current usage is changing. Most of those verbs are used in progressive form. This phenomenon is found in Corpus of Contemporary American English (COCA) and British National Corpus (BNC) as well.

The grammarians like Leech (2004) and Swan (2009), call those verbs in different way but actually they refer to the same verbs. Names the verbs as 'anti-progressive verbs' (Leech, 2004) and titles them with 'non-progressive verbs' (Swan, 2009). However, in this study, the writer will use the term 'stative verbs' (Quirk et al., 1992).

This study will focus to investigate the forms and meanings of stative verbs in progressive used in American and British English through data from two corpora, either in spoken and written form. According to Bennet (2010), Corpus is a large, principled collection of naturally occurring examples of language stored electronically. There are two corpora that will be used in this study consist of Corpus of Contemporary American English (COCA) and British National Corpus (BNC). These corpora; COCA and BNC are free to access on internet (Davies, 2009). These corpora are taken because they represent English in general and become 'role model' of English in many countries especially from non-native English country, such as Indonesia in particular. Besides, American and British English are two national standard languages that are overwhelmingly predominant both in the number of distinctive usages and in the degree to which these distinctions are institutionalized: American English (AmE) and British English (BrE) (Greenbaum et al., 2003).

Therefore, this study aims to know what forms of stative verbs are used with progressive in corpus linguistics. Besides, to find out the meanings are carried out by the use of those verbs in the progressive tense, whether the verbs with progressive form use the same purpose that indicates 'a happening in progress' as the most salient function of progressive aspect or indicates 'permanence' as the characteristic of the stative verbs or there are other certain meanings and functions of using stative verbs in progressive form.

\section{Method}

This research used qualitative research design with descriptive qualitative approach. The method was used to analyze the data of COCA and BNC in order to find out the forms of stative verbs use with progressive and the meanings are implied by the form.

The data of the research were collected from two corpora; COCA and BNC. The procedures of collecting data were divided into four steps. First, the researcher opened the website of COCA and BNC by using websites address http://corpus.byu.edu/coca/ for COCA and http://corpus.byu.edu/bnc/ for BNC. Second, the researcher inserted the word that wants to be searched and save the data in computer. Third, the researcher selected the sentences to find the data that relevant with the research in corpora. Fourth, the researcher analyzed the data.

In analyzing the data, some techniques were used. First, the researcher analyzed the data in the syntactic level that is to; identify stative verbs use with progressive tense in Corpora. Second, 
the research analyzed the data in the semantic level that is; to investigate throughout context of each sentence (data) by relating it with the theory about stative verbs and progressive tense. Third, which is the last step; the researcher concluded the data that have been analyzed then saved it as the result of the study.

\section{Findings}

Finding is divided into two parts; forms and meanings of stative verb understand in progressive tense and forms and meanings of stative verb believe in progressive tense, as follows:

\subsubsection{Forms and Meanings of Stative Verb Understand in Progressive Tense}

The stative verb understand in progressive carries out temporariness meaning. It is used to talk about something that is in progress or ongoing at the moment of the speaking. It indicates something is happening now or is continuing to happen. The verb understand with temporariness is carried out by the stative verb understand in four types of progressive; present progressive tense, present perfect progressive, past progressive and future progressive as in:

a. The stative verb 'understand' in present progressive tense

"...So we're talking not in Texas? Now you're understanding. You mean Pennsylvania. Oh. I slumped down in my chair. Philadelphia, Pennsylvania, I thought. (COCA)"

"Now you need quite a bit of practice. You 're understanding them now very well erm if you don't practise them a bit well this is what happens (BNC)"

b. The stative verb 'understand' in present perfect progressive tense

"I would like him to keep the Santos tradition, "he said." He's bred to be a jockey. He's been understanding about racehorses since he was born." (COCA)

c. The stative verb 'understand' in past progressive tense

"...and once we were able to train the computer that that type of signal meant left, it started to go left and the computer was understanding what my brain was telling it."(COCA)

d. The stative verb 'understand' in future progressive tense

"My expectation is that the next governor will be understanding of the need to protect jobs and to keep from moving people to welfare, " Prez said." (COCA)

The stative verb understand in progressive also load temporariness and tentativeness. It is considered as mixed categories of meaning. The meanings are carried out by the stative verb understand in present progressive and past progressive as in:

a. The stative verb 'understand' in present progressive tense

"SIEGEL: Have you just banned Girl Scout cookies from the schools in Texas? Is that what I 'm understanding? Ms-COMBS: Banned them from sale during the school day... "(COCA)

b. The stative verb 'understand' in past progressive tense

"... and once we were able to train the computer that that type of signal meant left, it started to go left and the computer was understanding what my brain was telling it." (COCA)

Temporariness and emotiveness meaning also appear in the stative verb understand that is used with present progressive and future progressive tense as in:

a. The stative verb 'understand' in present progressive tense

"...they said and Obama said is really stretching their budgets to the absolute breaking point.

He said, "Now, Wall Street is understanding what some of that pain feels like. "(COCA) 
"At last, I think we can safely say that you are understanding the situation correctly.' Roman's voice was bitingly sarcastic." (BNC)

b. The stative verb 'understand' in present progressive tense

"When I'm a famous singer/songwriter I won't question people's names. I'Il be understanding and polite. I'll get it. "(COCA)

"I promise I won't smother her way Leona did me. I'll be understanding, but I won't spoil her, I'll be tough, but I won't lean on her too much."(COCA)

Emotiveness meaning is carried out by the stative verb understand in present perfect progressive, past progressive and past perfect progressive as in:

a. The stative verb 'understand' in present perfect progressive tense

"...my wife has always been understanding about my devotion to Gunga Din; she treats it the way she treats my lingering fondness for certain leftovers that my mother served me when I was a boy. "(COCA)

b. The stative verb 'understand' in past progressive tense

"...No one had showed for pick-up." Oh my God- "said Ann....She was apologetic. The teacher was understanding. Aaron was not." Mom, you're always late- "he said. (COCA)

C. The stative verb 'understand' in past perfect progressive tense

"...So instead, she told him that she'd told her mother, and that her mother had been understanding and helpful. While she was on the subject, she told her psychiatrist that it was her mother who'd suggested her husband take a week in Bermuda on his own." (COCA)

The last meaning carried out by the stative verb understand in progressive tense is tentativeness. The form is used to imply uncertainty. The stative verb understand in past progressive tense load this meaning as in:

"I was understanding maybe a third of what was said, "Corrigan recalls, " but I was smiling and nodding."(COCA)

\subsubsection{Forms and Meanings of Stative Verb Believe in Progressive Tense}

The stative verb believe in progressive tense carries out temporariness meaning. The meaning is loaded by the stative verb believe in present progressive, present perfect progressive, past progressive and future progressive:

a. The stative verb 'believe' in present progressive tense

"I think we've reached a point in our market that the American consumer is believing today that some of the Japanese, just by the very name, build better cars. "(COCA)

"Perhaps what we believe today is no better than the Sunday-school notions we were forced to discard yesterday and is different to us only because we are believing it today? Will today's faith look as embarrassing if we look back on it tomorrow?"(BNC)

b. The stative verb 'believe' in present perfect progressive tense

"I've been believing that all my life, because I never got treated nice by the police,' Hey, how you doing, ' or nothing."(COCA)

c. The stative verb 'believe' in past progressive tense

"He was believing working, and that was his job. His job was his life. Now, what letter are we doing?"(COCA) 
"...But If doubt is eventually justified, we were believing what clearly was not worth believing. But if doubt is answered, our faith has gown stronger still."(BNC)

d. The stative verb 'believe' in future progressive tense

"...and within two minutes the prize-winner will be believing that she knew all about him and had indeed been specially looking forward to meeting him. The Duke of Edinburgh has a different line."(BNC)

The stative verb believe in progressive tense load mixed categories of meaning; temporariness and emotiveness. The form with this meaning appear in the verb believe that is used with present progressive and past perfect progressive as in:

a. The stative verb 'believe' in present progressive tense

"How are people like me supposed to be heard and taken seriously if everyone is believing everything they are fed, and no longer thinking and fighting against the biggest scam of them all: the government?"(COCA)

'People are believing things that are not realistic.' If an athlete does not like our rules, he plays tennis or rides a bike. They know our rules and must abide by them."(BNC)

b. The stative verb 'believe' in past perfect progressive tense

“...But I had been believing a lie. Whom could I believe now? Whom could I trust?"(COCA)

"The kind of betrayal she'd been believing him guilty of was mean, petty-minded, and he was none of those things." (BNC)

The stative verb believe in progressive tense carry out mixed categories of meaning; temporariness and tentativeness. The meanings appear in the verb believe that is used with present progressive and past progressive as in:

a. The stative verb 'believe' in present progressive tense

"They probably are believing that I am a Romanian, he thought bitterly, or Russian, my pathetic father, afraid to lose job, gave me Russian name to curry favor with local political officer."(COCA)

"No, the murder of Lord Woodleigh was conceived here on Capri, I am believing. Perhaps because something called a stoup in a church was not so interesting enough as he had thought." (BNC)

b. The stative verb 'believe' in past progressive tense

"She probably was believing that he was Gods choice for her, that he was a great prophet of God, and that her destiny was to be with him through eternity!"(COCA)

\subsection{Discussion}

The result of the research shows that the stative verbs understand and believe are used with different types of progressive tense. The stative verb understand is used with present progressive, present perfect progressive, past progressive, past perfect progressive and future progressive. The stative verb believe appear with present progressive, present perfect progressive, past progressive, past perfect progressive and future progressive. Future perfect progressive is the only one types of progressive do not appear in corpora. Based on the data appear in all types of progressive, the researcher assumes that it is possible if the native speakers of English (American and British) use the stative verbs in all types of progressive tense. The most used types of progressive found in corpora are present and past progressive. The researcher argues that such phenomena took place due to the overgeneralization of the native speakers of English in using the stative verb in progressive tense. Overgeneralization defines as the process of extending the application of a rule to items that are excluded from it in the language norm. The term 
overgeneralization has been common in second language acquisition. According to Brown (2000), the process occurs as the second language learner acts within the target language, generalizing a particular rule or item in the second language-irrespective of the native language-beyond legitimate bounds. In this study, overgeneralizations not only happen in the second language learners but also in the native speakers of English in generalizing the rules of stative verbs in progressive tense.

The stative verbs in progressive tense carry out different kinds of meanings. The form is used to express temporariness, emotiveness, comprehension and mixed categories of meaning; temporariness and tentativeness, temporariness and emotiveness. This study show that the most imply meaning in the stative verbs that is used with progressive tense is temporariness. However, this meaning contradict with the theories stated. Leech (2004), states that the progressive are normally incompatible with the anti-progressive verbs, because of their unfriendliness to the progressive. Swan (2009), also states that the non-progressive verbs or stative verbs never or hardly ever used in progressive because they describe a state rather than an action. The sense of the verb and the form reverse each other. The stative verbs imply permanent while the progressive tense imply temporary.

\section{Conclusion}

The stative verb understand and believe are used with present progressive, present perfect progressive, past progressive, past perfect progressive and future progressive. There is no stative verbs appeared in future perfect progressive. Based on the data appeared, the researcher assumes that the phenomena of the native speakers of English use the stative verbs in progressive because overgeneralization of using the stative verbs in progressive tense. The stative verbs can appear in progressive which imply an activity however, the data of using the form in corpora imply stative. Therefore, it is against Leech (2004) theory. The stative verbs; understand and believe in progressive tense used to express temporariness, emotiveness, comprehension and mixed categories of all the meanings; temporariness and emotiveness, temporariness and tentativeness. Temporariness almost appears in all stative verbs that are used with progressive tense in corpora. However, it contradicts with the grammar rules of English stated by theorists Leech (2004) and Swan (2009).

\section{Acknowledgments}

A deepest gratitude goes to Prof. Dr. Abdul Hakim Yassi, Dipl., TESL., M.A. and Prof. Drs. H. Burhanuddin Arafah, M.Hum., Ph.D. as the lecturers of English Language Studies Program of Hasanuddin University, who guided the writer in doing this research patiently.

A special gratitude goes to Prof. Dr. M. L. Manda, M.A., M.Phil, Dr. H. Fathu Rahman, M.Hum and Dra. Herawaty, M.Hum.,M.A.,Ph.D. who gave suggestions and support to the writer. The writer also really grateful to all lectures of English language studies program of Hasanuddin University for sharing previous knowledge and being inspiring people for the writer.

\section{References}

Bennett G. R. (2010). Using corpora in the language learning classroom: corpus linguistics for teachers. Accessed on May 7, 2015. Retrieved from http://www.press.umich.edu/titleDetailDesc.do?id=371534

Brown, Douglas. 2000. Principles of Language Learning and Teaching Fourth Edition. USA: San Francisco State University.

Davies M. (2009). The 385+ million word corpus of contemporary American English (1990-2008+) Design, architecture, and linguistic insights. International Journal of Corpus Linguistics, 14 (7): 159-190. 
Fromkin V. \& Rodman R. (1974). An Introduction to Language. United States of America: Holt, Rinehart and Winston.

Graver B.D. (2001). Advanced English Practice Third Edition. Oxford: Oxford University Press.

Greenbaum. et al. (2003). A Student's Grammar of the English Language. England: Longman Education Limited.

Griffiths P. (2006). An Introduction to English Semantics and Pragmatics. Great Britain: Edinburgh University Press.

Huddleston R. et al. (2002). The Cambridge Grammar of the English Language. Cambridge: Cambridge University Press.

Leech G. (2004). Meaning and English Verb Third Edition. London: Routledge, Tylor and Francis Group.

Quirk. et al . (1992). A Grammar of Contemporary English. England: Longman.

Swan M. (2009). Practical English Usage Third Edition. Oxford: Oxford University Press. area of Bulukumba Regency. Journal Ethical Lingua, 3 (2): 103-113 